\title{
"THE WERSTE LAY THAT EUER HARPER SANGE WITH HARP": THE FORMS OF EARLY MIDDLE ENGLISH SATIRE
}

\author{
by Ben Parsons*
}

\begin{abstract}
There is a persistent view in criticism which characterizes satirical discourse in Middle English as profoundly conservative. It is routinely asserted that satirical discourse was capable only of simple moral pronouncements, and that it was predisposed to champion the ideals and conventions it drew upon. The article challenges this conception. It revisits some of the earliest examples of satire in English to counter such a view, paying particular attention to the texts collected in Jesus College MS 29, and the Harley MSS 913 and 2253. Through examining these sources, a range of more scurrilous and defamatory devices are identified. Far from being inflexibly censorious, satire is found to have a strong element of deprecation and deflation in its arsenal of techniques. The article also reviews existing scholarship on medieval vernacular satire to suggest how existing conceptions of the literature may be refined, to reflect the findings it reaches.
\end{abstract}

Although sometimes dismissed as marginal or ill-defined, the corpus of satirical poems in Middle English has attracted a large volume of commentary. ${ }^{1}$ Since the publication of Samuel Tucker's Verse Satire In England a century ago, studies dedicated to medieval English satire have made sporadic appearances. ${ }^{2}$ The list includes contributions by John Peter, V. J. Scattergood, George Kane, Paul Miller and Laura Kendrick, to name just a few. ${ }^{3}$ While this commentary is not as extensive as critical work on Renaissance or Restoration satire, it has proved impressively cohesive. It has generated an idea of Middle English satire which most studies have upheld in some measure. Although this may not constitute a full-scale critical model, it does contain a number of key generalizations that are still widely accepted. Even recent work is

"English Department, University of Leicester, LE2 1ZB, UK (bptutor@yahoo.co.uk)

${ }^{1}$ For doubts about the cohesion and even the existence of Middle English satire, see Gilbert Highet, The Anatomy of Satire (Princeton 1962) 44-46; Thomas H. Bestul, Satire and Allegory in Wynnere and Wastoure (Lincoln, NE 1974) 86.

${ }^{2}$ Samuel Marion Tucker, Verse Satire in England Before the Renaissance (New York 1908).

${ }^{3}$ John Peter, Complaint and Satire in Early English Literature (Oxford 1956); V. J. Scattergood, Politics and Poetry in the Fifteenth Century (London 1971); George Kane, "Some Fourteenth-Century 'Political' Poems," Medieval English Religious and Ethical Literature, ed. Gregory Kratzmann and James Simpson (Cambridge 1986) 82-91; Paul Miller, "John Gower, Satiric Poet," Gower's Confessio Amantis: responses and reassessments, ed. A. J. Minnis (Cambridge 1983) 79-105; Laura Kendrick, "Medieval Satire," European Writers: the Middle Ages and the Renaissance, ed. William T. H. Jackson, 2 vols. (New York 1983) 1.337-375. See also Charles E. Davidson, "Middle English Verse Satire" (Ph.D. diss., Yale University 1953); Carter C. Revard, "The Medieval Growl: Some Aspects of Middle English Satire” (Ph.D. diss., Yale University 1958). 
reliant on this corpus of opinion, honoring its early promoters as "seminal" and "authoritative."

It is the purpose of the present essay to examine some of the claims this scholarship has made of medieval English satire, especially regarding its overall form and the strategies available to it. It will be suggested how these generalizations may be refined, in order to reflect more fully the discourse they describe. This is not to say that the findings of previous critics will necessarily be rejected here. On the contrary, most of their key assumptions will not be challenged: the bulk of their remarks remains accurate and useful, taking into account several important features of medieval English satire. However, it is also argued that these findings often prove to be unduly restrictive, offering a conception of satire that excludes much pertinent material. In short, the current article will outline some of the ways in which the conventional view of medieval satire might be expanded, by assessing common critical thinking in the light of early satiric discourse in English.

Before beginning this inquiry, however, it is important to give some account of the central issue under consideration, especially since the very notion of satire in Middle English has often proved contentious. Until comparatively recently, there was a general reluctance to use the term satire when referring to Middle English texts. This is despite the wide recognition that "from the thirteenth century on, there are a number of extant writings that ... may well be grouped together on the basis of their predominating concern with contemporary political, social, ecclesiastical or moral conditions." ${ }^{, 5}$ When approaching this literature, a variety of other, less precise designations have been preferred, such as Douglas Gray's "the satiric," Thomas Wright's "political songs," or James Sutherland's "school of primitives." The hesitation to classify these texts as satire seems to be based on two interlinked assumptions. First, it presupposes that there was little knowledge of Roman satire in the Middle Ages, and the medieval traditions that resemble it in form or

\footnotetext{
${ }^{4}$ James M. Dean, “Anticlerical Poems and Documents: Introduction," Medieval English Political Writings, ed. James M. Dean, TEAMS Middle English Texts (Kalamazoo 1996) 45.

${ }^{5}$ John Edwin Wells, A Manual of the Writings in Middle English, 1050-1400 (New Haven 1927) 208.

${ }^{6}$ Douglas Gray, "Rough Music: some early invectives and flytings," English Satire and the Satiric Tradition. ed. Claude Rawson (Oxford 1984) 21; Thomas Wright, ed., The Political Songs of England: From the Reign of John to that of Edward II (London 1839); James Sutherland, English Satire (Cambridge 1958) 23.
} 
intention may not therefore be accurately labeled satire. Second, as a result of this ignorance it is assumed that medieval "satiric" discourse lacked any unifying core, and that any relationship between texts must be accidental, not the result of any shared, coherent programme. Thus J. P. Sullivan states that classical satire failed to "dictate a form" for the Middle Ages, while John Norton-Smith speaks of a handful of medieval writers "taking to satire" only "instinctively" or "habitually," with no conventions to follow or models to emulate. ${ }^{7}$ Examining Middle English satire as a broad, generic designation would therefore seem intrinsically problematic.

Nonetheless, over the last three decades scholarship has done much to overturn these notions. It has become clear, for instance, that satire was one of most widely studied and discussed of the classical genres. The Roman satirists occupied a key place on the curricula of the medieval schools. As is well-known, once "new educational structures were generated during the long twelfth century," classical literature gained a new centrality in schooling. ${ }^{8}$ Students were introduced to the works of Roman poets at the earliest stages of their education. "Grammatica," the first of the arts of the trivium, drew on classical texts as it equipped the student with a basic knowledge of Latin. ${ }^{9}$ Amongst these texts, satires were particularly favored: Juvenal and Horace usually headed the selections from ancient writers, probably "to assure the medieval reading community" of the "moral standing" of pagan literature generally. ${ }^{10}$ In some cases, such literature stood at the very entry-point of literate culture itself. As Rita Copeland notes, the forthright and unambiguous nature of Juvenal and Persius rendered their work the "preferred genre for teaching Latin - and thus literacy - to young boys." Owing to this contact in the schoolroom, the terms satiricus and satura became firmly entrenched in the intellectual vocabulary of the Middle Ages. They were routinely discussed in medieval scholia: numerous surveys of the form occur in exegetic works, including Guido da Pisa's

\footnotetext{
${ }^{7}$ J. P. Sullivan, "Satire," The Legacy of Rome: A New Appraisal, ed. Richard Jenkyns (Oxford 1992) 219; John Norton-Smith, William Langland (Leiden 1983) 47, 53.

${ }^{8}$ R. N. Swanson, The Twelfth-Century Renaissance (Manchester 1999) 12.

${ }^{9}$ See The Seven Liberal Arts in the Middle Ages, ed. David L. Wagner (Bloomington 1983).

${ }^{10}$ Suzanne Reynolds, Medieval Reading: Grammar, Rhetoric and the Classical Text (Cambridge 1996) 1, 11.

${ }^{11}$ Rita Copeland, Pedagogy, Intellectuals and Dissent in the Later Middle Ages: Lollardy and ideas of learning (Cambridge 2001) 79.
} 
commentary on Dante (ca. 1387) and John Ridevall's commentary on Augustine (ca. 1333). ${ }^{12}$ Further summaries are found in handbooks of rhetoric, such as those of Matthew of Vendome and John of Garland. ${ }^{13}$ In fact awareness of satire proved sufficiently pervasive to be make its way into English. In the fourteenth century John Trevisa gave an extensive account of the "pre poetes specialliche i-cleped satirici," while at the end of the fifteenth Henry Watson dubbed his work a "boke satyryke," comparing it to "the poesyes and fyccyons/ of the auncyent poetes." satire. Two examples are the alliterative pieces Wynnere and Wastoure (ca. 1352-1370) and Mum and the Sothsegger (ca. 1420), each of which either refers to ancient satire directly, or draws on the conception of satire put forward by medieval commentary. Wynnere seems to be partly based on Juvenal's fifth satire, as it contains a lengthy description of two contrasting banquets, one of "venyson with the frumentee and festanttes full riche," the other of "pe roughe of pe rye" and "pe grewell gray." 15 In the case of Mum, Paul Miller notes that its author uses of the word "tente" when setting out his position: this is evidently an English equivalent of intentio, a common term for the objectives of satirists used throughout medieval scholia. ${ }^{16}$ Along similar lines, Vincent Gillespie also notes that "the insouciant antifeminism" of much medieval satire may not merely result from "the all-male atmosphere of most educational institutions," but might also register "echoes ... of Juvenal's writing." 17

\footnotetext{
${ }^{12}$ Guido da Pisa, Expositiones et Glose super Comediam Dantis, ed. Vincenzo Cioffari (Albany 1974) 5; Beryl Smalley, English Friars and Antiquity in the Early XIVth Century (Oxford 1960) 319

${ }^{13}$ Matthew of Vendome, Ars Versificatoria: the art of the versemaker, trans. Roger P. Parr (Milwaukee 1981) 27; The Parisiana Poetria of John of Garland, trans. and ed. Traugott Lawler (New Haven 1974) 103.

${ }^{14}$ Polychronicon Ranulphi Higden monachi Cestrensis, III.40, IV.9, trans. John Trevisa, ed. Joseph Rawson Rumby, 9 vols. (London 1865-1886) 4.179, 407; Sebastian Brant, Stultifera nauis, trans. Henry Watson (London 1509) fol. 8.

${ }^{15}$ Elaine Treharne, ed., Old and Middle English, c.890-c.1400: an anthology (Oxford 2004) 543-544.

${ }^{16}$ Paul S. Miller, "The Medieval Literary Theory of Satire and Its Relevance to the Work of Gower, Langland and Chaucer" (Ph.D. diss., Queen's University, Belfast 1982) 240. On "intentio" in satire commentary, see Udo Kindermann, Satyra. Die Theorie der Satire im Mittellateinischen. Vorstudie zu einer Gattungsgeschichte (Nuremberg 1978) $37-39$.

${ }^{17}$ Vincent Gillespie, "From the Twelfth Century to c.1450," The Cambridge History of Literary Criticism, ed. H. B. Nisbet et al. (Cambridge 1989-2005), vol. 2, The Middle Ages, ed. A. J. Minnis and Ian Johnson (2005) 227.
} 
Owing to the prevalence of Roman satire in literate culture, it is perhaps advisable to see Middle English satire as a response to the satirists of antiquity. Even if this reaction did not always take the form of direct imitation, it seems at least likely that medieval satirists found in their ancient counterparts a precedent and a justification for their own projects. ${ }^{18}$ This in turn means that satire in medieval English can be said to possess a reasonable level of cohesion: as S. T. Knight asserts, it was anchored to the "firm basis of auctoritee" that Roman satire supplied. ${ }^{19}$ While this does not mean that English satire can be considered a mere offshoot of the Roman models, since it voices its own concerns and developed its own traditions and topoi, it does suggest that there is sufficient underlying unity to treat the literature as a consolidated discourse. Satire in Middle English may be viewed as a fairly well-defined set of practices, supported by a single basic foundation, not as a haphazard or anachronistic categorization.

When interpreting this discourse, most critics have tended to follow broadly the same course. Perhaps the best summary of this line of thought is provided by Laura Kendrick. Kendrick's theoretical comments spell out a line of argument which recurs throughout criticism of medieval vernacular satire. Identifying the medieval discourse as "didactic" rather than "political," she states that:

The purpose of didactic satire is to convince the intended audience not to do something the satirist considers, for whatever reason, wrong ... the satirist criticizes deviation from a standard of behavior, more or less clearly defined and generally accepted by his audience. ${ }^{20}$

This reading of satire assigns a particular set of functions or tactics to the literature. According to this view, satire works by placing its chosen subjects in the context of the ideals they should pursue, explicitly comparing them with established models or "standards of behavior." The

\footnotetext{
${ }^{18}$ In recent years there has been a growing tendency to see other traditions in medieval satire in these terms: see Giovanni Orlandi, "Classical Latin Satire and Medieval Elegaic Comedy," Latin Poetry and the Classical Tradition, ed. Peter Godman and Oswyn Murray (Oxford 1990) 97-114; A. J. Minnis, Magister amoris: the Roman de la Rose and vernacular hermeneutics (Oxford 2001) 82-119; Robert Hollander, Boccaccio's Dante and the Shaping Force of Satire (Ann Arbor 1997) 69-88; Suzanne Reynolds, "Orazio satiro: Dante, the Roman satirists, and the medieval theory of satire," The Italianist XV, Suppl. 2 (1995) 128-144.

${ }^{19}$ S.T. Knight, "Satire in Piers Plowman," Piers Plowman: critical approaches, ed. S. S. Hussey (London 1969) 281.

${ }^{20}$ Kendrick (n. 3 above) 341.
} 
aim of this comparison is to use any points of difference or departure to condemn the subject, considering the disparities as "deviations," as failings, crimes or sins. This in turn serves to defend the ideals which satire draws on: in the first place, it treats them as indisputable criteria; in the second, it prevents violations of these standards from occurring in practice, stigmatizing any breach of them, and convincing the "audience not to do something." In short, this interpretation of Middle English satire suggests that it is a deeply conservative form, which serves to entrench conventional moral ideals. Similar views can be found outside Kendrick's work. James Sutherland, for instance, also states that "our earliest satire ... is generally marked by direct denunciation," describing it as a form of moral reproof. ${ }^{21}$ David Fowler follows much the same course, linking medieval vernacular satire with Lent, "wisdom, death, and repentance." 22

In every important respect, this reading of satire proves coherent and tenable. It cannot be denied that there is a strongly constructive element in medieval satiric discourse. In the literature as a whole there is an undeniable reliance on established criteria in formulating attacks. ${ }^{23}$ It is at this point, however, that this critical position becomes problematic. The chief difficulty lies in its general refusal to progress any further. Most critics regard the processes just outlined as the limit of medieval satire. These procedures are not simply treated as widespread in Middle English satire, but are deemed to be the only ones the literature may perform. Even when critics do detect different processes at work in specific texts, they tend not to broaden their findings to address satire as a whole: likewise, studies which call attention to less well-noted features have not met with wide acceptance. ${ }^{24}$ Satire in the Middle Ages is routinely denied the ability to do anything but reinforce the standards that it draws on.

\footnotetext{
${ }^{21}$ James Sutherland, English Satire (Cambridge 1958) 23-24.

${ }^{22}$ David C. Fowler, The Bible In Middle English Literature (Washington 1987) 75.

${ }^{23}$ See for instance Anne Hudson, Premature Reformation: Wycliffite texts and Lollard history (Oxford 1988) 22; Frantisek Graus, "The Church and its Critics," Anticlericalism in Late Medieval and Early Modern Europe, ed. Peter A. Dykeman and Heiko A. Oberman, Studies in Medieval and Reformation Thought 51 (Leiden 1993) 70.

${ }^{24}$ See for instance Thomas D. Hill, "Parody and Theme in the Middle English 'Land of Cokaygne,"” Notes and Queries 22 (1975) 55-59; Earl Birney, "English Irony Before Chaucer," University of Toronto Quarterly 6 (1937) 538-558; Carter Revard, "The Lecher, the Legal Eagle, and the Papelard Priest: Middle English Confessional Satires in MS. Harley 2253 and Elsewhere," His Firm Estate: Essays in Honor of Franklin James Eikenberry, Tulsa Monograph Series 2 (Tulsa 1967) 54-71.
} 
This limitation is not only implicit. Several commentators openly state that medieval satire may only "persuade the audience that certain behavior is wrong." 25 Such a claim is especially prominent in the work of Paul Miller. In his study of Middle English satire, Miller denies that satire can act as anything but a buttress for conventional standards. At one stage he cautions against reading medieval texts as challenges to any value-system. He states that "no medieval writer" would have wished to confront the dominant ideologies of the day, seeking only to "correct those whom he censures."26 This obviously excludes a large range of possibilities from satire. If the discourse must always gesture towards a positive standard in its attacks, wholly defamatory tactics are outside its range. It may not deflate its target entirely, since it must believe that the codes related to that target are valid and worthwhile. Nor may it play with or interrogate the ideals it draws on, since its purpose is to reinforce such ideals. Making correction the overriding intent of Middle English satire banishes any disrespectful, playful or ironic tendencies from the form. Satire may not be scurrilous, and may not denigrate the ideals associated with its subject-matter.

Far from being atypical, Miller's comments represent an enduring current in criticism. Another critic who describes medieval "reprobative literature" as a solely dogmatic form is John Peter. According to Peter, satire in Middle English possesses "more or less doctrinal attitudes" and is firmly "tied to a system ... and an accepted and enduring system too." For him, its chief concern is "always to be sober and reasonable, if occasionally severe ... like the Christianity it espouses." Again, it is in essence "corrective," and such techniques as "urbanity, malevolence, raillery, scurrility, cynicism," even "comedy" and "ribaldry," are outside its scope ${ }^{27}$ For Peter, no true derogation is possible in medieval satire, as every attack must be constructive, reinforcing an "accepted and enduring system." The same point occurs in the work of Gilbert Highet. Highet agrees that "the smile of satire" vanished during the Middle Ages, as medieval satirists were at root "unremittingly serious and doggedly systematic." It is his opinion that "in the world where Christianity had to make its way ... no believer could jeer about

\footnotetext{
${ }^{25}$ Kendrick (n. 3 above) 340.

${ }^{26}$ Miller (n.14 above) 241, 206

${ }^{27}$ Peter (n. 3 above) $9-10,57$.
} 
truth." ${ }^{28}$ Like Miller and Peter, Highet asserts that medieval satire held conventional ideals to be sacrosanct, and placed them utterly beyond dispute.

The core ideas of Peter and Highet echo throughout subsequent criticism. Even when not explicitly stated, the notion that medieval satire was essentially "corrective" hovers behind many discussions. It is particularly noticeable in the tendency to conflate satire with the mode that modern scholars have dubbed "complaint" or "protest literature.,"29 Complaint is one of the most robust traditions in medieval verse, with many examples extant in both Latin and English. Its conventions were already fully developed by the sixth century, and remained unchanged at the close of the Middle Ages: for example, its framework is equally evident in Gildas's account of the "guilty and thieving" Saxons, and in the first stanza of Chaucer's "Lak of Stedfastnesse." ${ }^{\text {"30 }}$ The complaint typically takes the form of a catalogue, recounting a series of proverblike moral pronouncements. The following lines, dating from ca. 1300, typify the form:

Bissop lorles,

Kyng redeles,

Yung man rechles,

Old man witles,

Womman ssamles.

I swer bi heuen kyng,

Pos bep fiue liper ping. ${ }^{31}$

As these lines makes plain, the complaint is firmly judgmental. It functions by condemnation, fixing each of its objects to a particular species of "liper" behavior. The fact that these categories are expressed negatively marks each as a transgression of some more valid behavior:

\footnotetext{
${ }^{28}$ Highet, Anatomy of Satire (n. 1 above) 44, 46. For a critique of Highet's analysis of medieval texts, see Edward Witke's review of The Anatomy of Satire in Classical Philology 58 (1963) 260-264.

${ }^{29}$ On the conventions of this form, see Joseph Keller, "The Triumph of Vice: a formal approach to the medieval complaint against the times," Annuale Mediaevale 10 (1969) 120-137; R. H. Nicholson, "The State of the Nation: Some Complaint Topics in Late Medieval English Literature," Parergon 23 (1979) 9-28; Siegfried Wenzel, Preachers, Poets and the Early English Lyric (Princeton 1986) 174-185.

${ }^{30}$ Gildas, The Ruin of Britain and other works, trans. and ed. Michael Winterbottom (London 1978) 29; Geoffrey Chaucer, "Lak of Stedfastnesse," 15-7, ed. R. T. Lenaghan, The Riverside Chaucer, ed. Larry D. Benson et a. (Oxford 1990) 654.

31 "Abuses of the Age, I," in Rossell Hope Robbins, ed., Historical Poems of the XIVth and XVth Centuries (London 1959) 144.
} 
"witles" is a lack of wit; "ssamles" a lack of shame; "rechles" a lack of prudence, and so on. Thus, the complaint always gestures towards a positive ideal in its attacks. In this, it resembles Laura Kendrick's conception of satire. But the complaint is even more unilateral than Kendrick's definition. Its framework bars any further implications. The complaint does not leave space for anything but acceptance of the ideals it cites. Since the entire point is to issue the briefest possible verdict on each object, no room remains for further engagement. This also demonstrates an absolute confidence in the ideals that are quoted. The lack of further discussion suggests that each gives a total account of the object. For instance, the term "rechles" gives such a thorough summary of the "yung man" that no further comment is needed. The poem is convinced of the validity of these norms. It sees no need to distrust or defy them. The complaint is moral exhortation in its purest possible form.

What makes this simple verse-formula relevant here is its frequent inclusion in discussions of Middle English satire. ${ }^{32}$ The complaint is often categorized as a variety or type of medieval satire. One influential critic to assume this stance is John Yunck. While "examining ... medieval satire through the analysis of its individual themes," Yunck describes complaint as a natural part of his inquiry. He denies that any point of separation exists "between satire and the literature of protest," and goes on to develop a notion of satire which comfortably accommodates this second form: "much of the material examined on the following pages may be best described cautiously as moral-satirical." 33 The work of Thomas Kinney presents a comparable view. Kinney also merges complaint into satire, situating the two forms in a single tradition, and often treating the terms interchangeably. ${ }^{34}$ More recently, Kathleen Fahey has edited an anthology specifically dedicated to "satirical poems in Middle English." This likewise regards complaint as a variant of satire. Introducing her collection, Fahey echoes Yunck in her

\footnotetext{
${ }^{32}$ On the distinction between the two forms, see Nicholson, "The State of the Nation" (n. 29 above) $9-28$.

${ }^{33}$ John A. Yunck, The Lineage of Lady Meed: the Development of Medieval Venality Satire (Notre Dame 1963) 5.

${ }^{34}$ Thomas L. Kinney, "The Temper of Fourteenth-Century English Verse of Complaint," Annuale Mediaevale 7 (1966) 74-89.
} 
firm rejection of "any distinction that can be made between satire and complaint." 35

By including complaints under the heading of satire, these critics reveal a comprehension of medieval satire in line with Peter's and Highet's. Even though Yunck and Fahey both criticize Peter's work as "not ... especially fruitful," their willingness to consider "imprecise lamentation over the evil of the time" as a form of satire is founded on much the same outlook. ${ }^{36}$ If such pieces can be classified as satirical, this again makes satire essentially moralistic. Exhortation is all that a text needs to demonstrate in order to be termed satiric. Any other activity is reduced to secondary importance. As Fahey explicitly states, satire becomes "by its very nature a complaint." ${ }^{37}$ Measuring objects against accepted standards, in order to fortify those standards, becomes the chief objective of every satirical text.

However, despite the prevalence of this view in criticism, it does not adequately reflect the practices of medieval satire. Identifying the complaint with satire gives a somewhat false and limited view of the literature. Medieval English contains many texts which display a far greater range of satirical techniques than simple rebuke. From the middle of the thirteenth century onwards, a body of work emerges in English which cannot be comfortably viewed as straightforward exhortation. While it is true that these pieces do contain an element of reproof, it is difficult to view this as their sole or even their ruling aspect. They employ a set of devices which are more elaborate than those of complaint literature, with more varied ramifications. Moreover, the recurrence of certain features in these texts suggests that a degree of confrontation and negation is integral to this discourse. In sum, the evidence suggests that satire in Middle English was intrinsically complex, and quite distinct from the complaint in its conventions.

This may be demonstrated by reviewing a few instances of satirical discourse in medieval English. The texts themselves reveal that Fahey, Yunck, and Peter's view is too narrow, laying undue emphasis on the remedial implications of satire. A good source of such work is Oxford,

\footnotetext{
${ }^{35}$ Kathleen A. Fahey, "Some Shorter Satirical Poems in English from the Thirteenth to the Early Sixteenth Centuries" (Ph.D. diss., Oxford University, Bodleian College 1991) 2 .

${ }^{36}$ Yunck (n. 3 above) 5; Kirk Combe, "The New Voice of Political Dissent: the Transition from Complaint to Satire," Theorizing Satire: essays in literary criticism, ed. Brian Connery and Kirk Combe (New York 1995) 77.

${ }^{37}$ Fahey (n. 35 above) 2.
} 
Jesus College MS 29. This manuscript is noteworthy for containing several of the earliest satirical poems written in English. While it is difficult to establish the precise date of these pieces, most seem to have been composed during the middle of the thirteenth century. The manuscript itself has been dated to 1285-1300, but appears to be based on an older exemplar. ${ }^{38}$ Some of its texts can even be traced back to the twelfth century, such as the Poema Morale, initially composed in ca. $1170 .{ }^{39}$

The satirical pieces preserved in the Jesus College manuscript are notable for using numerous comic and aggressive effects. Throughout these texts there is a conspicuous willingness to play with ideals as much as to enforce them. Two pieces of particular interest are "Sinners Beware" and "A Lutel Soth Sermun." ${ }^{40}$ Neither of these can be called wholly satiric, as both are clearly devotional works, but each one does contain several passages of sustained derision. Embedded in the first is what may be the earliest "estates satire" in English. ${ }^{41}$ Like later examples of the estates tradition, the text offers a comic survey of "the whole nation, conceived as a set of occupations or estates. ${ }^{, 42}$ This section of the poem begins by railing against the various orders of the church, dedicating a sestet to each. The tone of these is typical of the poem as a whole:

pes Munekes wenep summe.

pat gederep gersumme.

Pat heo hit schulle bruke.

Ah hwen dep schal cume.

${ }^{38}$ Betty Hill, "Oxford, Jesus College MS 29, Part II: contents, technical matters, compilation, and its history to $c$. 1695," Notes and Queries 50 (2003) 268-276.

${ }^{39}$ See Neil Cartlidge, "The Composition and Social Context of Oxford, Jesus College, MS 29 (II) and London, British Library, MS Cotton Caligula A.ix.," Medium Evum 66 (1997) 250-269; Selections from Early Middle English, ed. Joseph Hall (Oxford 1920) 30-46; Betty Hill, "The Twelfth-Century Conduct of Life, formerly the Poema Morale or A Moral Ode," Leeds Studies in English 9 (1977) 97-144.

40 "Sinners Beware" and "A Lutel Soth Sermun," in Richard Morris, ed., An Old English miscellany containing a bestiary, Kentish sermons, Proverbs of Alfred, religious poems of the thirteenth century, EETS o.s. 49 (London 1872) 72-83, 187-191. Subsequent references to these poems appear in parentheses in the text.

${ }^{41}$ On the estates tradition, see Ruth Mohl, The Three Estates in Medieval and Renaissance Literature (New York 1962) 21-34; Jill Mann, Chaucer and Medieval Estates Satire: the Literature of Social Classes and the General Prologue to the Canterbury Tales (Cambridge 1973).

42 James Simpson, Reform and Cultural Revolution, 1350-1547, Oxford English Literary History 2 (Oxford 2004) 246. 


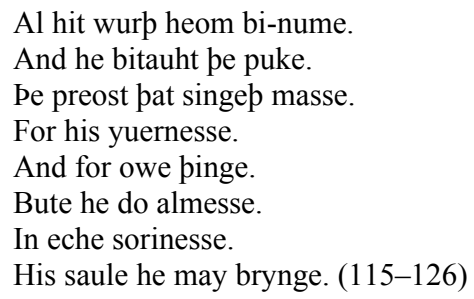

After this sequence, it moves on to secular professions, displaying particular disdain for "playdurs ... wel kene/ Pat weriep red and grene" and "chapmen monye bi stréte" (133-134, 139). The poem's appraisals reach as far down the social scale as "pe bonde" who "mest swynkep ... of alle men a londe," before concluding with a lengthy attack on women: "Peos prude leuedies./ Pat luuyep drywories./ And brekep spusynge./ For heore lecherye" (145-146, 157-160).

In this survey, the poem uses tactics that are alien to the complaint. Rather than simply fixing each class to a specific form of deviation, it often ironically plays with the distinction between the proper and improper. In its description of knights is a case in point. The poem states:

Pes knyhtes beop so bolde.

Hwenne heo habbep aquolde.

Heore crystene ivére.

Ah sathanas be olde.

Pe saule wule at-holde.

And makie heo vnfere. (127-132).

Of particular interest here is the use of the word "bolde." ${ }^{43}$ The poem is condemning the knights in terms normally used to praise them: for example, "bolde" is one of Layamon's favorite epithets for Arthurian "cnihtes bolde, a pousend itolde." ${ }^{44}$ In this context, the courage of the "knyhtes" becomes not only an aspect of their ideal behavior, but also the force that motivates their sin. By employing this stratagem, the poem steps beyond the strictures of complaint. Owing to this use of irony, the ideal and the sin may not be clearly differentiated. The same root cause underlies both, as boldness can be both malicious and beneficial. "Sinners" lacks the clarity of complaint. It does not smoothly fix

\footnotetext{
${ }^{43}$ The Oxford English Dictionary (henceforth OED) states that "stout-hearted, courageous, daring, fearless" has been the primary sense of "bold" since ca.1000.

${ }^{44}$ Layamon's Brut, ed. G. L. Brook and R. F. Leslie, EETS o.s. 250, 277, 2 vols. (London 1963-1978) 1.643 line 11391.
} 
its objects to sins, as when Gildas writes that "Britain has kings, but they are tyrants; she has judges, but they are wicked." ${ }^{, 45}$ Instead, it blurs the distinction between the offence and the ideal it contravenes.

This irony has further effects, which cause "Sinners" to depart even further from direct condemnation. The piece is not straightforwardly reproving the "knyhtes" by attacking their deviation from a valorized ideal. Instead, it slyly mocks the ideal itself. By using the word "bolde" to describe wrongdoing, with its connotations of correct knightly conduct, the poem implies some flaw in those ideals. The implication seems to be that the knights' models of behavior can lend themselves to treachery and gallantry with equal ease. The fact that the word itself is polysemous, possessing a second, more negative meaning, only confirms this. ${ }^{46}$ At the level of their root cause, chivalry and the killing of "crystene ivére" become indistinguishable. The same term can describe both. Thus, the standards of this class are the target here as much as the knights' departure from them. The poem is not simply contrasting the real and ideal forms of the object at the expense of the former. It is also calling the validity of the ideal into question, refusing to reinforce it as a positive norm. The tactics employed in "Sinners" are more scabrous than those of complaint literature.

The second piece, "A Lutel Soth Sermun," is even more forceful in its satire. About a third of the way through the text, the "Sermun" interrupts its account of the Fall and the Passion to list various types of sexual degeneracy:

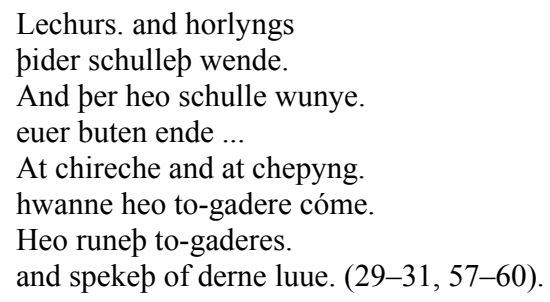

This soon expands into a bawdy account of the romantic dalliances of "maydenes" and "prude yongemen" $(53,55)$. In vivid terms, the poem details a brief but costly affair between one "Robyn" and "Gilothe":

\footnotetext{
${ }^{45}$ Gildas (n. 30 above) 29.

${ }^{46}$ The OED records usages of "bold" in the sense of "audacious, presumptuous, too forward" from ca. 1200 onwards.
} 
He may quyten hire ale. and seoppe don pat gome. An eue to go myd him. ne pinchep hire no schome. Hire syre and hire dame. pretep hire to béte.

Nule heo fur-go Robyn.

for al heore préte.

Euer heo wule hire skere. ne com hire no mon neyh. Forte pat hire wombe. vp aryse an heyh. (73-88).

As Thomas Hahn has noted, this section of the poem is "clearly in competition with other English poetical narratives that exhibit learned affinities but no overt intention to improve their readers." The specific examples Hahn gives are Dame Sirith and The Fox and the Wolf, both overtly comedic texts. ${ }^{47}$ In this sequence, the "Sermun" seems to be borrowing techniques from pieces designed purely for entertainment. In light of this, the poem's intent does not appear to be strictly hortatory. The purpose of this text does not seem be exclusively didactic, since it is drawing on conventions which do not function along these lines. The piece may also be seeking to amuse, to achieve something other than issuing pure directives. The description of the "prude" youngsters is in fact noticeably more scoffing than corrective in tone. Although it does make such statements as "at hom is hire pater noster," it seems more concerned with pillorying "wilekyn and watekyn" for their "swipe gled eye" than with pinpointing their exact sins, or measuring them against a positive standard $(66-67,71)$. The sequence eventually concludes with a general appeal to "godemen for godes luue," addressing all Christians rather than spelling out the exact abuses it has portrayed:

Bidde we seynte Marie.

for hire Milde mode.

For be theres pat heo weop.

for hire sune blode. (89-96).

The poem does not fully conform to the habits of complaint: it aims to do more than outline a simple moral code.

\footnotetext{
${ }^{47}$ Thomas Hahn, "Early Middle English," The Cambridge History of Medieval English Literature, ed. David Wallace (Cambridge 1999) 81.
} 
At the very least these texts demonstrate that medieval English writers could employ a range of humorous and playful devices in their attacks. Even at this early date, there is evidence to challenge the notion that "the satiric variations ... lie beyond the range" of medieval writers. ${ }^{48}$ These are complicated texts, demanding more from the reader than simple acquiescence. The use of comedy in the Jesus College poems introduces features which are not entirely consistent with exhortation. Their ribaldry and parody passes beyond straightforward moral censure, and may not be easily reconciled with this objective. Nevertheless, it must be admitted that there are limits to this. The poems do retain a firm attachment to conventional morality. For instance, the "Sermun" may suspend any ethical schemata to deliver its attacks, but this is only momentary: the verse ends on a pious note, invoking "seynte Marie./ for hire Milde mode" (93-94).

However, other satiric poems do go a little further. Several poems from the same period directly subvert conventional ideals, and even interfere with moral appraisal itself. A number of texts along these lines are found in Harley MS 913, compiled in Ireland no later than $1330 .{ }^{49}$ A particularly good example is the best-known piece in the manuscript, the much-anthologized Land of Cokaygne. ${ }^{50}$ At first glance, this seems to be a fairly typical description of Cockaigne, the fantastic edible land which appears in many medieval literatures. ${ }^{51}$ Like several other texts, it describes Cockaigne as a paradise in which cooked geese fly through the air honking "al hote al hot," and rivers of "oile, melk, honi, \& wine" flow past buildings "al of pasteiis" $(104,46,54)$. Usually the text is considered a typical specimen of Cockaigne-literature. For instance, Robert Elliot and John Scattergood treat it as a "basically wishful"

\footnotetext{
${ }^{48}$ Peter (n. 3 above) 10.

${ }^{49}$ On the date and provenance of the Harley MS, see A. M. Lucas and P. J. Lucas, "Reconstructing a Disarranged Manuscript: the case of MS Harley 913, a medieval Hiberno-English Miscellany,” Scriptorium 14 (1990) 286-299; on the contents, see esp. K. Reichl, "Satire und politische Lyrik in der anglo-irischen Kildare-Handschrift," Zeitgeschehen und seine Darstellung im Mittelalter, ed. Christoph Cormeau (Bonn 1995) $173-199$.

50 "The Land of Cokaygne," Old and Middle English, ed. Treharne (n. 15 above) 431435. Subsequent references appear in parentheses in the text.

${ }^{51}$ On analogues in Middle Dutch, Italian and French, see Herman Pleij, Dreaming of Cockaigne, trans. Diane Webb (New York 2001) 33-44, Carlo Ginzburg, The Cheese and the Worms: the Cosmos of a Sixteenth-century Miller, trans. John Tedeschi and Anne Tedeschi (Baltimore 1980) 82-86; Veikko Vaananen, "Le 'fabliau' de Cocagne," Neuphilologische Mitteilungen 48 (1947) 3-36. On onomastic references to Cockaigne across Europe, see Malcolm Jones, The Secret Middle Ages (Stroud 2002) 145-146.
} 
piece, an outpouring of "desire. ${ }^{, 52}$ However, as Wim Tigges has noted, the poem is in fact using this topos strategically, and for ends that are firmly satirical. Cokaygne is really a patchwork of several utopian ideas, a 'superimposition' of numerous "variants of the Other World." 53 Cockaigne is not the only locus amoenus outlined in the poem. The fabulous island is forced to share the verse with the Christian "peradis." From the outset the two are established as neighbors: the "lond ihote cokaygne" is statedly positioned "under heuen riche," made to share a border with this rival ideal (2-3). The two are even compared with one another. At one stage the poem directly contrasts the two: "po3 peradis be miri \& brizt,/ cokaygn is of fairir sizt" (5-6).

What makes the poem significant in the light of Highet and Yunck's conception of satire is its deliberate undercutting of any moral judgment. The proximity of these two paradises unsettles any idea of an absolute, universal truth. Both Heaven and Cockaigne are, in Herman Pleij's phrase, "fantasies of the perfect life." 54 They gather together the best possible conditions for existence, each one representing a notion of goodness at its most fully achieved. But it must be noted that each supposes a very different idea of what constitutes goodness. Heaven, at least as it is presented in the poem, stands for the denial of appetite. It possesses no "met bote frute," and no "halle, bure, no benche" (10-12). Its idea of perfection is only arrived at through "fastidious devotion to simplicity," as Krishnan Kumar writes. ${ }^{55}$ Self-restraint is its criterion of goodness. Cockaigne, on the other hand, valorizes the pursuit of "sensual satisfaction ... wishing away all physical and sensual limitation." Cockaigne represents carnal pleasure as a means of measuring goodness. Its idea of perfection is attained by giving free reign to bodily appetite. Each of these landscapes therefore assumes a different system by which merit can be reckoned. In one case physical pleasure determines value, while in the other withstanding temptation has the same function. This also has moral implications. Heaven and Cockaigne each promote a different form of human conduct as an ideal. As Cockaigne's

\footnotetext{
${ }^{52}$ Scattergood (n. 3 above) 353; Robert C. Elliott, The Shape of Utopia (Chicago 1970) 5 .

${ }^{53}$ Wim Tigges, "The Land of Cokaygne: sophisticated mirth," A Companion to Early English Literature, ed. N. H. G. E Veldhoen and Henk Aertsen (Amsterdam 1988) 98.

${ }^{54}$ Pleij (n. 51 above).

${ }^{55}$ Krishnan Kumar, Utopianism (Buckingham 1991) 6.

${ }^{56}$ J. C. Davies, "The History of Utopia: a Chronology of Nowhere," Utopias, ed. Peter Alexander and Roger Gill (London 1984) 8.
} 
notion of goodness lies in indulgence, it licenses such behavior. Heaven's emphasis on forbearance has the same effect, valorizing moderation.

This creates an interesting set of circumstances in the poem. Since each system is made to neighbor the other, it becomes difficult to derive any definite moral from the piece. The notion of correct conduct becomes plural and uncertain. Consequently, any appeals to definite notions of decency are rendered problematic. Cokaygne does not appear to champion behavior that conforms to a widely accepted standard, as Fahey and Peter insist that all medieval satire should. Instead, it establishes multiple standards, creating disparity in the very conception of goodness.

When "a wel fair abbei/ of white monkes \& of grei" is introduced, this indeterminacy gains a satirical edge (51-52). The behavior of this order is as riotous as the landscape permits: there "nis no spech of no drink" in its cloisters, and "pilk monke pat slepib best" is most likely to become "uadir abbot" $(111,175-176)$. Sexual license is also evident, as the monks routinely head to a nearby convent, and "techip pe nunnes an oreisun/ wip iambleue vp \& dun" (165-166). This scurrilous caricature obviously has some moral resonance, implying that the monks have little interest in the asceticism, celibacy and contemplation they ought to pursue. While they subscribe to Cockaigne's ideal of indulgence, they should be following Heaven's abstinence. This is a clear moral judgment, comparing the object's conduct to its proper ideal at the expense of the former. However, as Thomas Hill observes, Cokaygne also veers its attack away from the reality, towards one of the central tenets of monastic life. According to Hill the poem "recalls one of the great themes of monastic literature: the tradition of the "paradisus claustralis,' the cloistered paradise." When the poem speaks of Heaven, as Hill notes, it is actually referring to the monastic notion of paradise, its belief that its austerity "is the earthly type of the 'order' of heaven." Hence the "peradis" depicted by the poem is markedly ascetic, containing nothing "bot watir man-is purst to quenche" (12).

The "superimposition" of Cockaigne next to this quasi-monastic Heaven means that the latter can no longer be considered the sovereign notion of goodness. The monks' desire to emulate Heaven through their strict and austere regimen is directly challenged. The poem points out

${ }^{57}$ Hill, "Parody and Theme" (n. 24 above) 55-56. 
that this is not the only idea of goodness in existence. The monastic "fantasy of the perfect life" loses its dominance and authority. It becomes simply one of many rival conceptions. As a result of this, Cokaygne begins to ridicule the pretensions of monasticism. The poem is not only comparing the conduct of monks to the patterns of behavior they ought to be following, but is also calling those ideals into question. It is partly undercutting the standing of such ideals, rather than simply reinforcing them. In this, the poem demonstrates the range of devices which medieval satire could deploy. By using indeterminacy to undermine the status of monastic orders, it shows that Middle English satire does not only censure deviation. Cokaygne achieves far more than a straightforward recitation of "doctrinal attitudes ... applied to subjects already simplified." ${ }^{58}$ The poem's goal is closer to ridicule than reproof. It actively suspends moral sensibilities in order to execute its attacks.

What makes this all the more important is the simple fact that the tactics of Cokaygne are not particularly exceptional. Their complexity is mirrored by a number of poems in the famous Harley MS 2253, a collection apparently copied at Ludlow during the 1340s. ${ }^{59}$ Amongst these is the so-called "Satire on the Consistory Courts," a text which is very similar to Cokaygne in its basic strategies. ${ }^{60}$ The Satire takes the form of a monologue. It is narrated by a "lewed lued" who is brought before a bishop's court, having allegedly "on molde mote wip a mai" (4). The narrator produces several scathing attacks on the court during the course of the poem. The attending summoners are branded "mysmotinde men alle by here euene," while the bishop himself has "no wyt in is nolle" $(38,45)$. As it concludes, the narrator claims he is being persecuted: "atte constorie heo kennep vs care,/ ant whisshep vs euele \& worse to fare" (85-86).

Most readings treat the poem as a complaint, regarding its narrator's laments as simple moral appraisals. A number of critics follow Thomas Wright, and see the "Satire" as a direct indictment of "the smaller Ecclesiastical Courts, and the vexation which they caused to the peas-

\footnotetext{
${ }^{58}$ Peter (n. 3 above) 9.

${ }^{59}$ For a recent discussion, see Studies in the Harley Manuscript: the Scribes, Contents, and Social Contexts of British Library MS. Harley 2253, ed. Susanna Fein (Kalamazoo 2000); see also A Facsimile of British Museum MS. Harley 2253, ed. N. R. Ker, EETS o.s. 255 (London 1965).

60 "Satire on the Consistory Courts," in Robbins (n. 16 above) 24-27. Subsequent references appear in parentheses in the text.
} 
antry." ${ }^{\prime 61}$ The piece is frequently classified as plain "social criticism": Helen Barr, for instance, remarks that "its main focus is on the oppression that is caused by the language of the law." ${ }^{\prime 62}$ However, as George Kane points out, the "Satire" is much less clear-cut than this. It is if anything "more social comedy than complaint," as its "speaker ... is not favourably represented." ${ }^{, 63}$ Carter Revard reaches a similar assessment, describing the narrator as "a vindictive ... self-justifying type." ${ }^{.64}$ Any sense that the poem is a straightforward protest against a corrupt institution dissolves as it progresses. The narrator's own stance is deeply compromised. It quickly becomes apparent that he is guilty of the charges against him, and is not the innocent victim he claims to be. At one stage he reveals some highly incriminating knowledge, describing his accuser as unattractive beneath her headdress, or "vncomely vnder calle" (60). He is not the source of indisputable truth, or even an injured party, but a flawed and self-interested speaker.

However, it is no more true to state that he himself is an object of condemnation. The poem is not a sermon against fornicators any more than it is a complaint against bishops' courts. Much like Cokaygne, the poem creates a number of competing assessments. It is clear that two trials are underway in the poem. Just as the narrator is tried and judged, so he tries and judges the court with his invective. He even passes sentence on its personnel, saying that the clerks "shulen in helle on an hok/ honge pere-fore" (53-54). As the court seeks a verdict against him, so he delivers his verdict on the court. What is most significant here is that the poem avoids giving precedence to either set of judgments. It does not award primacy to the decrees of the narrator or the court. The court's sentence is not overturned. At length the narrator is forced to submit to its punishments, as he is married to his accuser by "a pruest proud ase a po" (82). Yet his own estimations of the court also stand unchallenged. His monologue is the only voice in the poem: no other speaker intervenes to correct or dislodge his insults. The poem is not delivering a single set of authoritative judgments: it is a neutral space in

\footnotetext{
${ }^{61}$ Wright (n. 6 above) 155.

${ }^{62}$ Helen Barr, Signes and Sothe: Language in the Piers Plowman Tradition (Cambridge 1994) 134. See also Saara Nevanlinna, Päivi Pahta, Kirsti Peitsara, and Irman Taavitsainen, "Middle English," Early English in the Computer Age: Explorations through the Helsinki Copus, ed. Matti Rissanen, Merja Kyto, and Minna Palander-Collin, Topics in English Linguistics 11 (Berlin 1993) 37.

${ }^{63}$ Kane (n. 3 above) 86.

${ }^{64}$ Revard (n. 9 above) 67. INCORRECT. IS THIS REF. TO N. 3 OR N. $24 ?$
} 
which two sets of appraisals converge, in which each judge is also the object of another's judgment.

The poem thus denies any central authority, in much the same manner as Cokaygne. The only real difference is that this is an end in its own right, rather than something turned against a particular target. Both the court and the accused are equally objects of mockery. The poem is even-handed in its denigration. It makes all positions equally open to question, rather than allowing any to become a privileged site from which secure rulings can be issued. Like Cokaygne, the "Satire" is not strictly a complaint. Its content expands beyond the narrow parameters of such work, and even challenges the moral certainties on which complaint literature is based.

It is safe to say that none of these poems are reducible to simple ethical vituperation. Although all involve some form of assessment, none can be termed straightforwardly didactic. They are complex pieces, using devices which do not occur in the complaint, and which are not merely variations of its methods. All share a tendency to play with ideals and judgments rather than demand allegiance to them. Even the most rudimentary of these works makes extensive use of irony, undercutting the values it appears to advocate. Each of the texts employs deflation at least as forcefully as it employs admonition, playing with codes rather than enforcing them in unambiguous terms.

Of course, it may be argued that these poems are anomalies rather than illustrations of a coherent literary trend. After all, a handful of disparate texts can hardly be considered a large-scale tendency in medieval poetry. However, there is evidence to suggest that these poems do represent a wider current. Each of the manuscripts so far mentioned contains numerous texts which use the same scabrous forms of attack, rather than one or two items in isolation. Harley 2253 is a particularly rich source of such literature. Along with the "Satire On The Consistory Courts," it preserves the mock-blazon "Annot and John," the coarsely antifeminist "On the Follies of Fashion," and the savage lampoon of Henry III's supporters "Against the Barons' Enemies." ${ }^{\circ 5}$ Likewise, Harley 913 contains other pieces which adopt the same broad

\footnotetext{
${ }^{65}$ See Theo Stemmler, "The Problem of Parody: Annot and John, for example," Genres, Themes and Images in English Literature from the Fourteenth to the Fifteenth Centuries, ed. Piero Boitani and Anna Torti (Tübingen 1988) 156-165; Francis Lee Utley, The Crooked Rib (Columbus, OH 1944) 182; "Against the Barons' Enemies," English Lyrics of the Thirteenth Century, ed. Carleton F. Brown (Oxford 1932) 131.
} 
stance as Cokaygne, such as the playful estates satire On the People of Kildare, and the anti-academic "Song of Nego." manuscript is "Pers of Bermingham," ostensibly a panegyric to Sir Peter de Bermingham, which Michael Benskin and Deborah Moore have identified as an example of "psogos" or mock-encomium. ${ }^{67}$ All of these poems attack by deflation, irony and direct mockery, rather than simply issuing rigid moral pronouncements which champion established codes.

Even the Jesus College MS preserves several texts which apply the same techniques. Similar processes are evident in the antipapal "Holy Chireche is vnder uote" (ca. 1271-1276). ${ }^{68}$ The poem opens with a parodic biblical gloss, which aims to "explain" the corrupt state of the contemporary church in scriptural terms. The poem assures the reader that it is fitting for simony to pervade the priesthood from "pe seolue pope" down, because St. Peter was still "i-cleped symon" when the "chireche" was "sette ... up-on" him $(1-3,29)$. This mockery is directed against both the ideal and the conduct of its object: the very foundation of the church is comically implicated in the critique, rather than hailed as an unquestionable standard. Also in the same manuscript is the famous $O w l$ and the Nightingale. ${ }^{69}$ If anything, this provides an even more striking use of satiric indeterminacy than Cokaygne. Numerous critics have noted its refusal to propose firm judgments and definitions. R. Barton Palmer describes the poem as "an interrogation rather than a declaration of 'meaning," while Douglas Peterson notes that it deliberately suspends any "final verdict.", This suspension is achieved by citing several criteria at once, rather than allowing one

66 "An Irish Satire," The Oxford Book of Medieval English Verse, ed. Celia Sisam and Kenneth Sisam (Oxford 1970) 156-158; "Song of Nego," in Wright (n. 6 above) 210 211.

67 "Pers of Bermingham," Die Kildare Gedichte: die ältesten mittelenglischen Denkmäler in angloirischer Überlieferung, ed. W. Heuser, Beiträge zur Anglistik 14 (Bonner 1904) 161-164; Michael Benskin, "The Style and Authorship of the Kildare Poems, (1) Pers of Bermingham," In Other Words: transcultural studies in philology, ed. J. L. Mackenzie and R. Todd (Dordrecht 1989) 57-75; Deborah Louise Moore, "Parody and Satire in the Medieval Cultural Productions of the South West Midlands and Anglo-Ireland' (MA thesis, University of Victoria 1996) 50-63. On Peter's career and reputation as the "epitome of the unapologetic English lord," see Robin Frame, "Power and Society in the Lordship of Ireland 1272-1377," Past and Present 76 (1977) 28-29.

68 "Whan holy chireche is vnder uote," in Morris (n. 40 above) 90. See Tucker (n. 2 above) 53 .

${ }^{69}$ The Owl and the Nightingale, ed. Neil Cartlidge (Exeter 2001).

${ }^{70}$ R. Barton Palmer, "The Narrator in The Owl and the Nightingale: a Reader in the Text," Chaucer Review 22 (1988) 307; D. L. Peterson, "The Owl and the Nightingale and Christian Dialectic," Journal of English and Germanic Philology 55 (1956) 26. 
position to dominate. There is no consensus in the poem as to how exactly the birds' various arguments should be verified. As Karen Gasser writes: "Where does one find the answer to the riddle of experience-in hedonism or in moral absolutism ... through logic-chopping, rhetoric, self-assertion, force, or ... tolerant accommodation?"71 There is no common standard for establishing superiority in the poem, but several competing models. As a result of this, the satire is turned against debate itself, or even against "human contentiousness" in general. ${ }^{72}$ The poem does not promote a single correct position, or a positive norm: on the contrary, everything it mentions is a target. As in "Consistory Courts" and Cokaygne, nothing is privileged, and everything is equally denigrated.

The existence of several poems which seek to undermine ideals, rather than simply to reinforce them, shows that such methods are by no means unusual in medieval English poetry. These forms of attack are not confined to a mere handful of texts. Several vernacular pieces seek to problematize given codes instead of simply to impose them, degrading the ideals surrounding their objects instead of treating them as infallible criteria. Short-circuiting conventional standards is clearly a key part of vernacular satire's range of techniques. Even at an early stage in Middle English poetry, derision and irreverence are important aspects of its satire.

In sum, the main point to stress is that Middle English satire is a highly complex literature. It does not necessarily act in a straightforwardly moralistic manner. The work of Yunck, Fahey and Kinney, which argues that these poems implement the same basic strategies as complaint literature for the same ends, begins to appear a little reductive when placed alongside the poems themselves. None of the poems so far discussed can be defined as purely sententious, delivering only simple moral decrees. At times they veer towards the abusive songs mentioned in romances, such as the "werste lay that euer harper sange with harp" composed by Sir Dinadan against King Mark. ${ }^{73}$ Even this brief review reveals that seeing satire as "moral-satirical" or "by its

\footnotetext{
${ }^{71}$ Karen M. Gasser, Resolution of the Debate in the Medieval Poem The Owl and the Nightingale, Studies in Medieval Literature 18 (New York 1999) 95.

${ }_{72}$ Kathryn Hume, The Owl and The Nightingale: the Poem and Its Critics (Toronto 1975) 102.

${ }^{73}$ Thomas Malory, Le Morte Darthur, X.27, ed. H. Oskar Sommer (London 1889) 458. For further examples, see Wells (n. 5 above) 177; R. M. Wilson, The Lost Literature of Medieval England, rev. ed. (London 1970) 124.
} 
very nature a complaint" does a disservice to the literature. At best this stance treats satire's more playful tendency as dispensable and superficial, regarding it as a digression from the form's real purpose. At worst, it flatly denies that satire may confront the ideals it cites. These assumptions render satire predictable and mechanistic, whereas it often proves more volatile and deflationary in practice. The fact is that Middle English satire is generally more than an exercise in pure didacticism. From its emergence in the thirteenth century, satire in English has deployed corrosive strategies as frequently and forcefully as it has used moral reprehension. 